\title{
Communicative Constitution of Organization for Elementary School in Pandemic Covid-19
}

\author{
Sigit Tripambudi1, Basuki Agus Suparno² \\ 1,2 Communication Department UPN “Veteran” Yogyakarta
}

\begin{abstract}
This study focuses on an organizational development especially for an elementary school in which try to stabilize and adopt the changes of teaching and learning processes in relate to pandemic Covid 19 since it has been prevailing one year ago. Through Communicative Constitution of Organization (CCO) approach, it stressed on how elementary school as organization develop and adapt toward the uncertainty situation affected by pandemic covid 19 . There are four locations which represent communication events in organization. First, membership negotiation, portraits how member of organization interact each other. Second, selfstructuring, reflects how organization norms and culture were internalized within member of organization. Third, activity coordination- the way assignment was conducted and accomplished. It is an important thing in determine organization being successful. And finally, position of institution determines organization to the public. All has important roles to shape and develop organization being success.
\end{abstract}

Keyword: Organizational development, CCO, an elementary school, adaptation, leadership

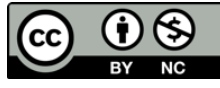

This is an open access article under the CC-BY-NC license

\section{INTRODUCTION}

Pandemic Covid 19 has serious implication to any kind of activities of human life including in education. It has been a year since all almost countries in the world, for instances Europe countries, Africa, as well as Asia including Indonesia warns how dangerous Covid 19 was.

Some regulations and laws were released to prevent the diseases spread out in the large that influence many sectors of services either public or private, small enterprise or corporation. It is unavoidable. All stops an operation. One of sectors which affected by Pandemic Covid 19 is education system especially elementary schools. Compared with Junior High School or Senior High School, an elementary school is the most risk than Junior or Senior High School.

In Piyungan Sub District Bantul, Yogyakarta, many have taken an impact seriously. Teaching and learning processes were disrupted and unpredictable. Nobody knows when this pandemic will end. On one other side, teaching and learning must be conducted, while several conditions were not properly to have teaching directly, face to face interaction.

Therefore, to synchronize this situation, it is necessary for an elementary school as organization must stabilize and adopt changes. It was functioned to sustain and survive for organization overcome several of difficulties that caused by Pandemic.

This study focuses on organization change and development as a response toward pandemic. Organization change was always important thing for organization to do adjustment frequently in order organization alive. An elementary school as a system interact to environment. What environment change will affect organization do. System needs stable condition. At the same It will regulate and control condition in order operation.

At this point, headmaster has important role in managing and leading his institution. He must lead creatively in facing the situation and ensure that his teachers, pupils, and clerks were always optimistic. Whatever happen, each of organization encourage themselves being survival. 
There are four locations that will be scrutinized in relate to how elementary school in Piyungan sub district make adjustment and overcome the difficulties. First, what we call membership negotiation. This term indicates that organization development can be seen from the quality and quantity of interaction. Latitude of acceptance or rejection in the organization in turn, affects an organization performance. Degree of solidity, influence a way the assignment and task accomplished.

The second location is self-structuring. We see duality processes that happen at any organizations. An individual in organization can be perceived as an actor that perform the duties. This performance will shape and re-shape organization life. On the contrary, organization that has norms and belief, are important values that directed organization to its own goals that will be obtained. Thus, we see duality of processes available here. Self-structuring processes depict a situation where organization internalize its vision and mission to members, and vice versa, member of organization contribute significantly for organization actions. It affects to member of organization

Viewed from this perspective, we see organizational resources and leadership in organization have important role to make it success or not. Leadership and change in organization are very close each other. Cliffort Geerzts and Pacanowsky argued that it was almost impossible changing organization unless leader roles (Griffin, 2004). In other word, leader determine direction of organization change, accepted or not even success or fail.

Due to two locations that mention above, the third location we call activity coordination. It indicates manner of actors in accomplishing the duties whether these were accomplished by an individual or a team. Activities coordination also reflect the way members collaborate and communicate a duty. What is a duty? This question means that how they define a duty, how duty will be communicated, how will it be executed and how will it be qualified.

Mutual understanding was needed for organization life so that the duties can be done well. Position of leader can be seen from way of organization distribute and allocate assignment. Leader has a variety of styles that play an important role for member in realizing all tasks done.

The telling mode is one of leader styles that point out that leader has an authority to instruct employee. It was used to ensure to whom look less self-motivated and incompetence in order moving on from condition. This style is useful to determine that the task can be executed correctly while employee hasn't enough information and detail.

Other is selling style. This style is useful when a leader wants to drive an employee in accomplishing the task with high quality standard. In this position, a leader is necessary giving an evidence that will be imitated by employees. There is available best platform as prototype for member of organization. Best practices are valuable assets for organization that organization makes progress.

The delegating style was the third mode that was performed when a leader will show that he believes employees can do something correctly. Each leader must consider what time will it be given to employees. Capacity and competence usually were considered as primary reason for a leader who will give task independently to an employee.

Participating style is other style in which a leader wants to exhibit that he can work together. This style can be used to lessen the gap between leader and employee. At this point, a leader also used this style to integrate nuances in organization being positive climate and organizational culture.

The last location in accordance with CCO approach is position of institution. The primary problem was laid on method and strategy of organization in presenting to public either internally or externally. Relation between actors and organization determine nuances of organization itself. Credibility and reputation can be raised from this matter. If member of organization resists to his own organization, it signifies that relation between organization and member was bad.

Communicative Constitution of Organization as perspective and theory were influenced by thought of Anthony Gidden about Structuration, Niklas Luhmann's system theory and thought of John Dewey's pragmatic. As approach, it is useful for understanding organizational change and development if we perceive organization as communication events. Because manifestation of 
organization as communication events itself, it can be seen from any processes of membershipnegotiation, self-structuring, activities coordination and position of institution. All are communication features.

From organization communication perspective, this article shall explore more detail about organization as communication events. This focuses on an elementary school as organization in facing pandemic Covid 19. By doing collaboration with United Teachers of Indonesia (PGRI) Piyungan Sub District, raw materials gained from discussion among stakeholders who have intertwined and involved at any situations that they have in their organization of school specifically an elementary school.

The main purpose of this research is to gain a model that depict the process and design how organization of school specifically organization of elementary school develop its organization in facing pandemic covid 19 through CCO approach. To synchronize and get data more comprehensive, we systematize data gained from headmasters and teachers in any cases they have in executing organization. Priorly, we invite an organization consultant to give short course about organization change and development. Later, we invite headmasters and teachers for discussion purposes.

These steps try to combine between idealistic-conceptual comprehension about organizational change and any praxis-the actual practices at elementary school during pandemic Covid 19. Hopefully, this combination gets qualified procedure so that it makes best model for organizational development.

\section{RESEARCH METHOD}

Research method that was used to gain model for organizational change and development is an action research. At this point, researchers facilitate social actors who manage and organize elementary schools to come together in formulating procedures, determining flow of authority, identifying roles, describing position, and explaining task as well as functioning of school management. Data collection was gained by offline-online forum during pandemic Covid 19. Frequently, researchers take time to depth interview and other time researchers open online forum to discuss together about matter that will be projected.

CCO (Communicative Constitution of Organization) was referred as theoretical framework. This categories into four locations as explained above. But it does not mean that each location stands independent even isolated apart from others. Otherwise, each location of CCO involve and engage to construct and re-construct forms of organization to stabilize situation cause of pandemic covid 19.

Being organization well, it requires capability of adaptation and adoption innovation especially information technology. School as organization need stabilizing and facing unpredictable situation like pandemic covid 19. Therefore, this model has significant relevance for balancing situation so that this institution can execute the business.

\section{RESULTS AND DISCUSSION}

\section{Short Brief}

Four aspects will be presented here to simulate how a model of organization development and change can be formed. First, idealistic-comprehension conceptual about organization development. In this aspect, thoughts of organization change from any scholars will be presented. It was intended to get the best portrait to what organization is and how organization sustain.

Second, aspect of interaction among members of organization. It reflects the actual interaction among members of organization. Dynamics of interaction is important thing to catch up nuances of organization. Degree of acceptances among members is one factor for organization to survive.

Third, socialization processes that happen in organization when it wants to internalize the organization norms, or vision and mission, values as well as beliefs to members. Proud of organization can be viewed from sense of belonging among members. Personal and organization identity is 
inherently interchangeable. What goals members seek in organization are manifestation of what goals organization were dedicated.

Fourth, cooperation displayed by members. The way they accomplish assignment will inform much about their method and strategy to finish the jobs. How they manage the time and how they cooperate with others are important thing that must be counted. Distribution of task relate to competencies and capability. A leader plays an important role to accelerate, monitor, inspect and ensure that the assignment was done.

\section{Conceptualization Process}

Some of headmasters have given opinions in relate to how they perceive and manage the schools when pandemic was still prevailing. One of them argued that it was impossible teaching student directly during Pandemic. They have reasons. First, government has released regulation to stop any activities that make crowd including activities in education system. It prevails either an elementary school or junior high school.

According to them, the second main problem is degree of difficulties that was faced. Student in elementary schools can be compared with student who was in junior or senior high school. Student in elementary schools still need a lot of guidance and instructions. Teachers and parents must consolidate each other and work together in order the program can proceed and success. Parents must accompany their children to fulfill minimize obligation from schools. On other side, schools must adjust and prepare a system that can be accommodated and accepted all participants including the parents.

At this point, among parents, teachers and headmasters ensure what the system and program will be implemented. On other side, school as education institutions must develop and adapt toward situation during pandemic. What organization will do? What kind of organization will be needed to synchronize the situation?

Intensified interactions were becoming important thing to handle and overcome situation. Headmasters leads meeting and at the same time involve any activities to ensure the program can be conducted well. At emergencies situation during Pandemic, position and organization development determine steps that will be taken.

All factors that reflect condition of organization influence and determine organization performance in facing crisis. A variety of factors encompass role of headmasters, interaction quality among member of organization, sense of belonging and responsibility toward vision and mission, characteristic of organization doing the assignment and jobs, and public perception to organization.

Therefore, understanding of management and organization is a key for doing adjustment and change. In other word, headmaster must perform as leader that motivate and drive his employee to ensure that organization run well and correct direction. Teachers have commitment and integrity in doing assignment and task. Climate and organizational culture are conducive for working. Solidity and cooperation were growing up among them. Mechanism, procedures and conventions were functioned to control the duties whether it was done well or not. These are factors in determining organization develop

They argued that as public servant who work at schools owned by state, have never stopped working. Whatever situation that they have, all must dedicate his time and power to fulfill responsibility to educate and teach students. Therefore, for those who work from home, they frequently coordinate their task either offline or online forum. Headmasters and teachers re-formulate and re-define the concept and mechanism for teaching and learning processes.

\section{Solidity of Organization}

Acceptance or rejection is crucial issue in organization. If one of members was accepted by others, it will affect to him more comfortable when he is working and cooperating. On contrary, if one 
of them was rejected among them, it will make him stress and distress. This effect will escalate to work quality and results. Therefore, solidity of organization plays an important thing for organization.

Cases in elementary schools in Piyungan Sub District Bantul, Yogyakarta portrait unique characteristics. First, albeit, schools are formal institution, but interaction among them reflect non formal, warmth, and kinship relationship. Solidity of organization illustrates relationship among them. Acceptance or rejection was influenced by stance of person in organization. Viewed from Symbolic Interactionism, the way we perceive to thing or person, was defined by the way other see us.

Penetration can be happened when we open ourselves. Self-disclosure plays significant roles to shape nuance of interaction. When one tends to mask his personality, other will also de-penetrate from others. In organization, members of organization were banded by motivation for working. But, it does not mean that relations and inter-relations in organization is an easy to be form. Failure can be happened because of interaction matters.

Second, we see that characteristic of interaction among members of elementary School in Piyungan Bantul, Yogyakarta was influenced by Javanese morality and Islamic values. We noted that tolerance and cooperation were core concept to figure out the nature of interaction. They develop substantial value to respect to others. The older guarantee the younger and motivate them to increase the capacity and capability. Headmaster treats all members of organization as family. He performs any kind of position, sometimes perform like father, other time as a friend and so on. They argued that they follow Ki Hajar Dewantara tenets as following as:

a. Whoever is ahead, he must perform the best integrity and conduct

b. Whoever is in middle, he must perform the initiative and inspiration

c. Whoever is in the behind, he must perform the best participant to support

By this principle, they can build mutual understanding and respectful. Any problem that raised cause of inter-relations was solved by personal approach. During pandemic, there are a lot of technical matters that disturb the concentration. It consists of wireless connections, digital divide, subject content for student as well as applications. All matters were approached through personal communication and working togetherness.

\section{Work and Co-Work: Activity Coordination}

Many things in organization must be distributed proportionally into a variety of lines. Each department is usually responsible for duties and task. Each person has specific term of duties and task that must be accomplished. He has agendas for general or specific purposes. They know when the agenda must be finished and when it will be examined and checked.

Report of duties and task regularly were presented and delivered to institution. Measurement and supervision toward productivity are routine taken to evaluate everyone who have finished the task. At the same time, activity coordination is a strategy to run organization obtaining the goal.

In this point, we can differ activity coordination into two types. First, each person independently has responsibility to his own job. He does not need cooperation and coordination with others. One can do the task without assistance. This condition can be perceived as individual and autonomy concerns. Sometimes this is about privacy matters. On the contrary, many things cannot be accomplished alone but, it needs an assistance for a help.

During pandemic, headmasters and teachers try to synchronize rhythm of working. Work from home model that was chosen government to avoid new cluster for Covid 19 insists them re-formulating teaching system. They spend much time to design and develop new model for teaching. Digital divide available among teachers, it does not automatically enlarge the gap. Those who master information technology assist colleague so that he has competencies in operating computer or software application. 
Co-working and co-partner were growing among them during pandemic Covid 19. Communication climate in elementary school

\section{Schools: Sense of Belonging}

Schools are organization in education system. From this view, we conceive that school as organization normally has vision and mission which guide organization works. The most important question in related to this issue is how these organization values were internalized within member of organization and vice versa. Assimilation is key concept to understand it why vision and mission were having failure be understood by members.

Organization development was also determined by condition which members perceive their interest and in turn, it reflects organization's concern. Headmasters and teachers perceive schools as location where they share and experience together in seeking a life. As public servant who paid by state, they understand that they must dedicate and devote time and energy for public interest especially in education field.

They argued that becoming a teacher is a choice. Thus, those who have chosen a teacher as profession, it should be responsible to what he took decision. Therefore, for them, schools are location where they live, where they dedicate, and where they experience all their life.

\section{CONCLUSION}

Each organization in education field including elementary schools in Piyungan, Bantul Yogyakarta tries to transform and adjust toward situation affected by pandemic Covid 19. For that reason, adaptation is unavoidable if it wants to stabilize organization. Failure or success of organization was not merely adaptation and adoption, but it also was influenced by capacity of organization develop effectiveness management that encompasses solidity of organization, the way organization accomplish assignment, and internalization of organization values. Leader plays an important roles in shaping organization run well.

Factors that have mentioned above signifies that solidity of organization, internalization of vision and mission, and activity of organization are determinant elements that orient organization obtain the ultimate goal. Elementary schools that locate in Piyungan Bantul Yogyakarta prove that factors which determine organization development are key factors that organization survive during pandemic Covid 19.

\section{References}

Barnard, C. I. (1938). The functions of the executive. Cambridge, MA: Harvard University Press. Em Griffin, 2002, A Look First at Communication Theory, Boston: Wadsworth

Francois Cooren and Thomas Martine, "Communicative Constitution of Organizations, in https://www.researchgate.net/publication/309394678, October 2016

Follett, M. P. (1995). Mary Parker Follett: Prophet of management. Ed. P. Graham. Washington, DC: Beard Books.

Littlejohn, W Stephen, 2000, Theories of Human Communication, Boston: Wadsworth

McPhee, R. D., \& Zaug, P. (2000). The communicative constitution of organizations: A framework for explanation. Electronic Journal of Communication/La revue électronique de communication, 10(1/2), 1-16.

Putnam, L. L., \& Nicotera, A. M. (Eds.). (2009). Building theories of organization: The constitutive role of communication. New York, NY: Routledge. Putnam, L. L., \& Pacanowsky, M. E. (1983). Communication and organization

2010, Communicative Constitution of Organization is a Question: Critical Issues for Addressing it, Management Communication Quaterly, Vol 24 Number 1 
RSF Conference Series: Business, Management and Social Sciences

Volume 1Number 4 (2021): 183-189

Communicative Constitution of Organization for Elementary School in Pandemic Covid-19

Sigit Tripambudi, Basuki Agus Suparno

Katherine Miller, 2009, Organizational Communication, Approaches and Processes, Boston: Wadsworth

Engage Learning

Tarde, G. (1899). Social laws: An outline of sociology. London, UK: Macmillan

Tripambudi, Sigit dan Suparno, Basuki Agus, 2020, Model Komunikasi Pembelajaran Multidimensi Dari Rumah di Masa Pembatasan Sosial bagi Siswa SD di Kecamatan Piyungan, Bantul Yogyakarta, Laporan Penelitian LPPM UPN Veteran Yogyakarta 